\title{
A 28-day, randomized, double-blind, placebo-controlled, parallel group study of nebulized revefenacin in patients with chronic obstructive pulmonary disease
}

Krishna K. Pudi ${ }^{1}$, Chris N. Barnes ${ }^{2}$, Edmund J. Moran ${ }^{2}$, Brett Haumann ${ }^{3^{*}}$ and Edward Kerwin ${ }^{4}$

\begin{abstract}
Background: Revefenacin is a once-daily long-acting muscarinic antagonist (LAMA) in clinical development for the treatment of patients with chronic obstructive pulmonary disease (COPD). In a dose-ranging study, nebulized oncedaily revefenacin had a long duration of action in patients after 7 days' administration of doses up to $700 \mu \mathrm{g}$. In this multiple-dose study, the bronchodilation efficacy and adverse events profile were characterized in patients administered nebulized revefenacin once daily for 28 days.
\end{abstract}

Methods: A total of 355 COPD patients (mean age 62 years, mean forced expiratory volume in $1 \mathrm{~s}\left[\mathrm{FEV}_{1}\right] 44 \%$ of predicted) were randomized in a double-blind, placebo-controlled parallel group study. Inhaled corticosteroids as well as short-acting bronchodilators were permitted. Once-daily treatments $(44,88,175$ or $350 \mu \mathrm{g}$ revefenacin or matching placebo) were administered by a standard jet nebulizer, for 28 days. The primary endpoint was change from baseline in D28 trough FEV ${ }_{1}$ and secondary endpoints included weighted mean FEV ${ }_{1}$ over 0 to $24 \mathrm{~h}$ and rescue medication (albuterol) use. Safety evaluations included adverse events, laboratory assessments, electrocardiograms and 24-h Holter profiles.

Results: Revefenacin $(88,175$ and $350 \mu \mathrm{g})$ significantly improved D28 trough FEV 1 over placebo $(187.4,166.6$ and $170.6 \mathrm{~mL}$, respectively, all $p<0.001) ; 44 \mu \mathrm{g}$ produced a sub-therapeutic response. At doses $\geq 88 \mu \mathrm{g}$, more than $80 \%$ of patients achieved at least a $100-\mathrm{mL}$ increase from baseline $\mathrm{FEV}_{1}$ in the first $4 \mathrm{~h}$ post dose compared with $33 \%$ of placebo patients. For doses $\geq 88 \mu \mathrm{g}$, D28 $24 \mathrm{~h}$ weighted mean differences from placebo for FEV 1 were numerically similar to respective trough $\mathrm{FEV}_{1}$ values, indicating bronchodilation was sustained for $24 \mathrm{~h}$ post dose. Doses $\geq 88 \mu \mathrm{g}$ reduced the average number of albuterol puffs/day by more than one puff/day. The $350 \mu \mathrm{g}$ dose did not demonstrate additional efficacy over that observed with $175 \mu \mathrm{g}$ revefenacin. Revefenacin was generally well tolerated, with minimal reports of systemic anti-cholinergic effects.

Conclusions: These data suggest that 88 and $175 \mu \mathrm{g}$ revefenacin are appropriate doses for use in longer-term safety and efficacy trials. Revefenacin offers the potential for the first once-daily LAMA for nebulization in patients with COPD who require or prefer a nebulized drug delivery option.

Trial registration: ClinicalTrials.gov NCT02040792. Registered January 16, 2014.

\footnotetext{
* Correspondence: bhaumann@theravance.com

${ }^{3}$ Theravance Biopharma UK Limited, London, UK

Full list of author information is available at the end of the article
} 


\section{Background}

Long-acting inhaled bronchodilators are recommended as maintenance therapy for chronic obstructive pulmonary disease (COPD) patients with moderate to severe symptoms or those who are at higher risk for COPD exacerbations [1]. These bronchodilators fall into two classes: long-acting muscarinic antagonists (LAMAs) and long-acting beta agonists (LABAs), with the once-daily LAMA, tiotropium, and the twice-daily LABAs, salmeterol and formoterol, being the most widely prescribed for COPD [2-4]. Moreover, monotherapy with a LAMA is considered a first-line therapy option for many patients with moderate to severe COPD $[1,5]$.

Long-acting inhaled bronchodilators are most often self-administered with hand-held devices such as pressurized metered-dose inhalers or dry powder inhalers $[6,7]$. Some patients, however, have difficulty using hand-held devices (eg, the elderly or cognitively impaired) $[8,9]$, which can result in inaccurate dosing, poor adherence and potentially poor clinical outcomes [10-12]. Nebulizers, which are easy to use and offer similar efficacy $[8,13]$, are an alternative to hand-held devices. Yet there are limited options for maintenance treatment with nebulized long-acting bronchodilators. Nebulized LABAs (Brovana ${ }^{\oplus}$ [arformoterol tartrate] and Perforomist ${ }^{\circ}$ [formoterol fumarate]) are currently available; however, these agents are labelled for twice-daily administration. Thus, despite the ascendency of effective and convenient once-daily LAMA bronchodilator therapy (tiotropium bromide) in clinical practice for both reversal of bronchoconstriction and control of acute exacerbations of COPD, and the recent emergence of additional once-daily LAMA, LABA/ICS and LAMA/LABA handheld products, no once-daily nebulized bronchodilator has been available to patients who require or prefer nebulized drug delivery [9]. Revefenacin is the first once-daily anti-muscarinic administered via a standard jet nebulizer to enter late-stage clinical development $[9,14,15]$.

Research has shown that revefenacin may produce sustained, long-acting bronchodilation similar to tiotropium bromide but with a lower potential for anti-muscarinic side effects (eg, dry mouth) [16]. In a randomized, double blind, repeat dose, placebo-controlled doseranging study, nebulized revefenacin (22 to $700 \mu \mathrm{g}$ administered for 7 days via a standard jet nebulizer) demonstrated a long duration of action and low systemic exposure in patients with COPD [17]. Moreover, doses $88 \mu \mathrm{g}$ and above produced clinically effective bronchodilation as measured by trough forced expiratory volume in $1 \mathrm{~s}\left(\mathrm{FEV}_{1}\right)$ and serial spirometeric assessments following the D7 dose [17]. The objective of this 28-day study was to identify appropriate revefenacin doses for longerterm safety and efficacy trials in patients with COPD. ${ }^{1}$

\section{Methods}

\section{Study design and conduct}

This randomized, double-blind, placebo-controlled, multiple-dose, parallel-group study, conducted at 41 centers in the United States between April 2014 and July 2014, evaluated the efficacy, safety and tolerability of revefenacin in patients with COPD (ClinicalTrials.gov NCT02040792). The study conformed to appropriate ethical guidelines and was conducted in accordance with the principles of the International Conference on Harmonisation of Technical Requirements for Registration of Pharmaceuticals for Human Use guideline for good clinical practice [18] and the code of ethics of the World Medical Association's Declaration of Helsinki [19], with all patients providing written informed consent.

\section{Patients and treatments}

Patients were men or women of non-childbearing potential (aged 40 to 75 years) with moderate to severe COPD [1] and a current or former smoking history of more than 10 pack-years, who at screening demonstrated a postipratropium bromide ratio of $\mathrm{FEV}_{1}$ /forced vital capacity of $<0.7$ and a $\mathrm{FEV}_{1}$ of $30-80 \%$ of the predicted normal value after withholding short-acting bronchodilators for $\geq 6 \mathrm{~h}$ and long-acting bronchodilators for $\geq 14$ days. In addition, patients were eligible for enrollment regardless of the numerical improvement in their $\mathrm{FEV}_{1}$ following bronchodilator (ipratropium bromide and/or albuterol) administration via a PARI LC ${ }^{\circ}$ Sprint nebulizer (PARI, Midlothian, Virginia, US) at screening. Patients who demonstrated reversiblity to placebo ( $\geq 12 \%$ change and $\geq 200 \mathrm{~mL}$ ) were excluded from the study.

Following the screening period (two or three visits no more than 50 days prior to D1 of the treatment period), patients were stratified at randomization based on responsiveness status to ipratropium bromide during screening (responsive or non-responsive, with responsiveness defined as $\geq 12 \%$ and $\geq 200 \mathrm{~mL}$ change in $\mathrm{FEV}_{1}$ 45 min after completion of ipratropium bromide nebulization). Randomized patients received a 3-mL inhalation solution of placebo or revefenacin $(44,88,175$ or $350 \mu \mathrm{g}$ ) administered once daily for 28 days from a PARI LC Sprint nebulizer. Dosing occurred in the morning and was self-administered, except on D15, D16 and D28, when patients were dosed at their clinical study center.

All study personnel, as well as the sponsor, site monitors and patients, were blind to treatment allocation throughout the study.

Concomitant therapy was managed during the study as follows: LABA and LAMA bronchodilators were prohibited; combination steroid and LABA therapy was discontinued and the steroid component was replaced with an equivalent strength steroid inhaler monotherapy. Albuterol was allowed as necessary but was requested to 
be withheld for $6 \mathrm{~h}$ before the initial spirometry assessment performed at each study visit and during the course of the entire visit when serial spirometry was performed (unless medically necessary).

\section{Assessments and endpoints}

For $\mathrm{FEV}_{1}$ assessment, spirometry was performed according to techniques consistent with the American Thoracic Society guidelines for spirometry [20] and conducted at specified time points during the screening visits and treatment period (D1 baseline [45 min and 15 min predose; 0 to $6 \mathrm{~h}$ postdose]; D15, D16 and D28 pretreatment trough [45 min and 15 min predose]; and D28/29 post treatment [0 to $24 \mathrm{~h}]$ ). Peak expiratory flow rate (PEF) was conducted by the participants each morning and evening throughout the treatment period and up to the post-treatment follow-up visit. Safety and tolerability were assessed based on adverse events (AEs), clinical laboratory findings, vital signs, physical examinations and/or electrocardiogram (ECG) readings obtained before, during and after the treament period. A diary was used for recording dosing times, rescue medication use, concomitant medications and AEs throughout the 28-day dosing period and the 1-week follow-up period.

The primary endpoint was change from baseline in D28 trough $\mathrm{FEV}_{1}$ (the mean of the 23.25-h and 23.75-h time points following the last dose on D28) measured on D29. Secondary endpoints included the D1 change from baseline of the weighted mean $\mathrm{FEV}_{1}$ over 0 to $6 \mathrm{~h}$ $\left(\mathrm{FEV}_{1(0-6 \mathrm{~h})}\right)$, and the D28 change from baseline of the weighted mean $\mathrm{FEV}_{1}$ over 0 to $12 \mathrm{~h}\left(\mathrm{FEV}_{1(0-12 \mathrm{~h})}\right)$ and 0 to $24 \mathrm{~h}\left(\mathrm{FEV}_{1(0-24 \mathrm{~h})}\right)$ (serial spirometry); time to a 100 $\mathrm{mL}$ increase from baseline on D1; change in PEF and use of albuterol rescue medication (puffs per day and percentage of rescue medication-free days).

Pharmacokinetic (PK) blood samples were obtained on D28 before dosing and post dose (at 0.25, 0.5, 1, 2, 4, 6, 8, 12, 24, 48, 72 and $96 \mathrm{~h}$ ) at selected sites and in 45 subjects. Concentrations of revefenacin were quantified using validated liquid chromatography with tandem mass spectrometry (lower limit of quantification of $0.005 \mathrm{ng} / \mathrm{mL}$ ). The analytical method for revefenacin was validated in K2EDTA (ethylenediaminetetraacetic acid) plasma, utilizing solid phase extraction. Revefenacin concentrations were calculated using a standard curve with a $1 / \mathrm{x}^{2}$ linear regression over a concentration range of 0.005 to $2.5 \mathrm{ng} / \mathrm{mL}$. The mass spectrometer (API-5000 ${ }^{\text {ma }}$ System [Applied Biosystems, Ontario, Canada]) was operated under optimized conditions for the detection of revefenacin in turbo ion spray, positive ionization and selected reaction monitoring.

\section{Statistical analysis}

Based on a sample size of 350 (70 participants assigned to each treatment group) and allowing for 45 dropouts, 60 completers in each group provided at least $80 \%$ power to detect an increase of $120 \mathrm{~mL}$ in trough $\mathrm{FEV}_{1}$, assuming a standard deviation of $200 \mathrm{~mL}$ and a $5 \%$ significance level.

The intent-to-treat (ITT) population was used for all efficacy analyses and included all participants who were randomized into the study and received at least one dose of study drug. The primary endpoint was analyzed using a repeated measures model, incorporating treatment group, smoking status, responsiveness to ipratropium bromide and/or albuterol, age ( $<65$ years or $\geq 65$ years) and sex as fixed effect class terms and a continuous covariate for baseline $F E V_{1}$. A random effect for subject and a time effect (D15, D16, D28 and D29) were also included in the model. Least squares (LS) means and 95\% confidence intervals (CIs) were calculated for the differences between each revefenacin dose and placebo on the primary endpoint, and statistical significance of pairwise comparisons were evaluated using the Benjamini-Hochberg step-up adjustment for multiple comparisons for the primary endpoint. A similar analysis methodology was used to assess the secondary spirometry endpoints and rescue medication use with no adjustment for multiplicity.

PK data were analyzed using summary statistics for all patients who provided PK data for at least one dose of revefenacin. Key PK parameters calculated included the time to maximum plasma concentration $\left(t_{\max }\right)$, the maximum plasma concentration $\left(\mathrm{C}_{\max }\right)$, area under the (AUC) plasma concentration-time curve from time 0 to $24 \mathrm{~h}$ $\left(\mathrm{AUC}_{0-24}\right)$ and from time 0 to the last detectable time point $\left(\mathrm{AUC}_{0-\mathrm{t}}\right)$ and terminal elimination half-life $\left(\mathrm{t}_{1 / 2}\right)$.

The safety population was used for all safety analyses and included all subjects who were randomized into the study and received at least one dose of study drug.

\section{Results}

\section{Patients}

In total, 355 patients were enrolled in the study (Fig. 1). One patient, identified as participating in another clinical study, was removed from the ITT population $(N=354)$ but retained in the safety population $(N=355)$. One patient receiving revefenacin $350 \mu \mathrm{g}$ was removed from the study on D6 due to a non-treatment-emergent prolonged Fridericia formula for QT interval correction (QTcF, $>500$ msc) revealed during the screening ECG but not reviewed by the investigator until post first dose. That subject is included in both the ITT and safety populations though the prolonged QTcF adverse event is not contained in the treatment-emergent $\mathrm{AE}$ summaries.

Patient demographics and key baseline characteristics, which were similar between treatment groups, are summarized in Table 1.

\section{Efficacy}

The primary endpoint, change from baseline in D28 trough $\mathrm{FEV}_{1}$, demonstrated significant benefit with revefenacin 


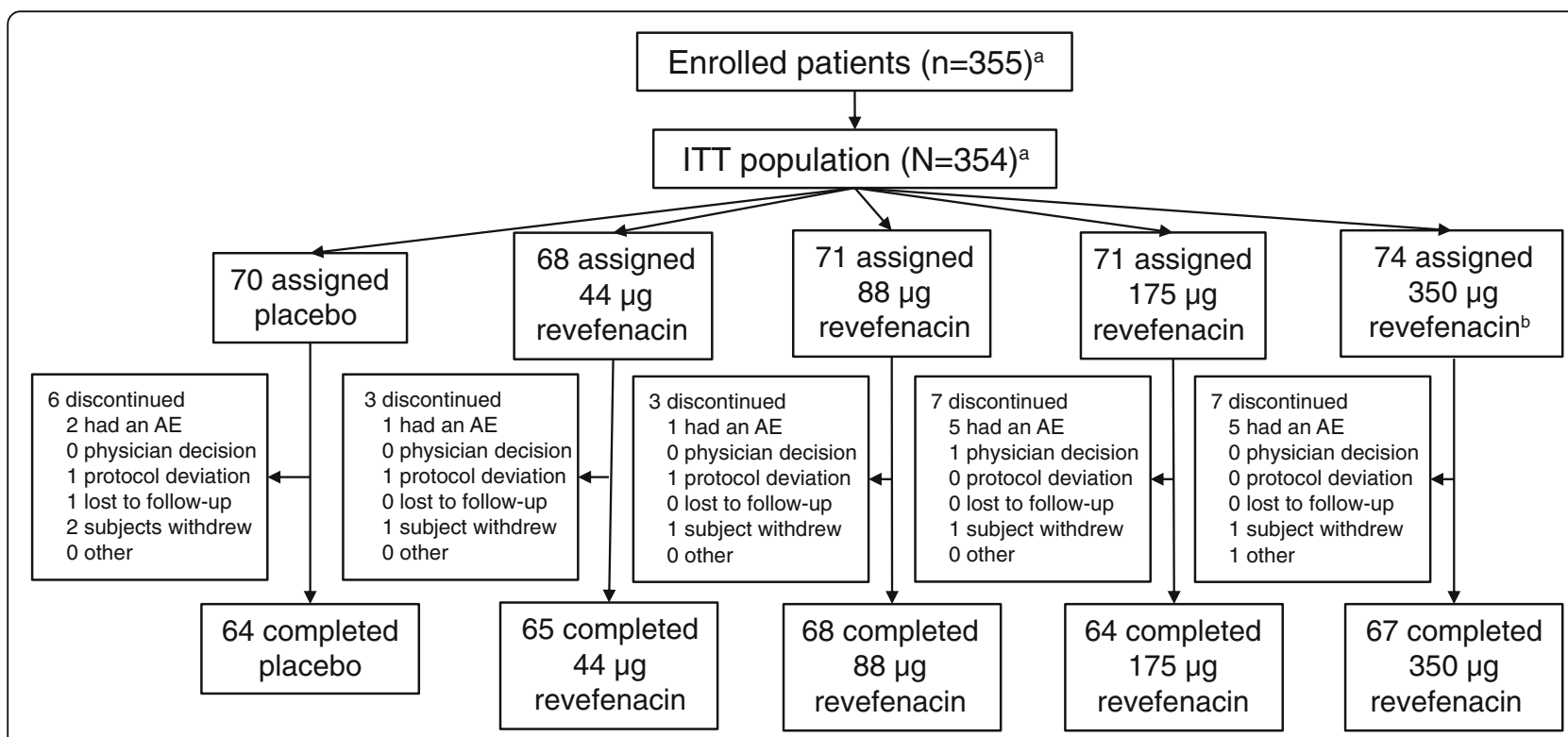

Fig. 1 Patient disposition (ITT population). ${ }^{a}$ One patient, identified as participating in another clinical study during this study, was removed from all efficacy analyses $(n=354)$ but retained in all safety analyses $(n=355)$. ' $O$ ne patient receiving revefenacin $350 \mu \mathrm{g}$ was withdrawn from the study by the investigator on D6 due to a non-treatment-emergent prolonged QTcF ( $>500 \mathrm{msc}$ ) during the screening electrocardiogram. The subject is included in both the ITT and safety populations though the prolonged QTCF adverse event is not contained in the treatment-emergent AE summaries. Abbreviations: AE: adverse event; ITT: intent to treat; QTcF: Fridericia formula for QT interval correction

over placebo for the three higher doses during the 24-h serial spirometry assessments (Table 2). On the D28 trough FEV 1 measured on D29 (Fig. 2a), revefenacin $88 \mu \mathrm{g}$ showed the largest improvement over placebo in trough $\mathrm{FEV}_{1}$ (LS mean [95\% CI], 187.4 [118.8, 256.1] mL; $p<0.001$ versus placebo) with the two higher doses also showing large improvements (166.6 [97.3, 263.0] $\mathrm{mL}$; $p<0.0001$ and 170.6 [101.9, 239.3] mL; $p<0.0001$, for 175 and $350 \mu \mathrm{g}$, respectively). A non-statistically significant and likely sub-therapeutic improvement was noted for $44 \mu \mathrm{g}(51.8[-17.3,121.0] \mathrm{mL})$.

On prior trough $\mathrm{FEV}_{1}$ assessments (D15, D16 and D28), revefenacin $175 \mu \mathrm{g}$ consistently outperformed the other two therapeutic doses (Fig. 2b) with mean additional improvements in $\mathrm{FEV}_{1}$ ranging from 25.7 to $58.1 \mathrm{~mL}$ relative to $88 \mu \mathrm{g}$ and ranging from 14.3 to $27.9 \mathrm{~mL}$ relative to $350 \mu \mathrm{g}$. All three higher doses produced improvements in trough $\mathrm{FEV}_{1}$ exceeding $100 \mathrm{~mL}$ during the 28 days of follow up, while the placebo group showed small declines.

Revefenacin demonstrated a rapid onset of brochodilation at all doses on D1 (Fig. 3). The median (95\% CI) time to achieve at least a $100-\mathrm{mL} \mathrm{FEV}_{1}$ increase from baseline on D1 was $30(30,60)$ minutes for both 88 and $175 \mu \mathrm{g}$ and $30(15,30)$ minutes for $350 \mu \mathrm{g}$ (nominal $p<0.001$ versus placebo for all doses). At doses $\geq 88 \mu \mathrm{g}$, more than $80 \%$ of patients achieved at least a $100-\mathrm{mL} \mathrm{FEV}_{1}$ increase from baseline in the first $4 \mathrm{~h}$ post dose compared with $33 \%$ of placebo patients. The three higher revefenacin doses showed mean improvements over placebo that exceeded $114 \mathrm{~mL}$ and were present by $1 \mathrm{~h}$ post dose on D1 and throughout all timepoints on D28 (Fig. 3). The D1 weighted mean $\mathrm{FEV}_{1(0-6 \mathrm{~h})}$ ranged from $145.1 \mathrm{~mL}(44 \mu \mathrm{g})$ to $214.9 \mathrm{~mL}(350 \mu \mathrm{g})$, with significant increases versus placebo noted for all doses (Table 2). Additionally, for doses $\geq 88 \mu \mathrm{g}$ on $\mathrm{D} 28$, differences from placebo for both weighted mean $\mathrm{FEV}_{1(0-12 \mathrm{~h})}$ and $\mathrm{FEV}_{1(0-24 \mathrm{~h})}$ values were numerically similar to respective trough $\mathrm{FEV}_{1}$ values, suggesting sustained 24-h bronchodilation.

Revefenacin decreased albuterol rescue inhaler use compared with placebo for the three highest doses. On average, placebo subjects used three puffs/day of rescue albuterol (Fig. 4a). Doses $\geq 88 \mu \mathrm{g}$ significantly decreased rescue medication use by a clinically relevant decrease of at least one puff per day in a dose-dependent manner $(p<0.005)$. Expressed as rescue inhaler-free days over the entire treatment period, revefenacin $175 \mu \mathrm{g}$ and $350 \mu \mathrm{g}$ increased the number of rescue-free days over placebo by $\geq 14 \%$ ( $p<0.05$; Fig. $4 \mathrm{~b}$ ), corresponding to an increase of approximately one rescue-free day per week.

Throughout the 28-day study period, revefenacin produced sustained increases in morning and evening PEF (Fig. 5); PEF measurements reached steady state early in dosing, prior to D7, and were maintained throughout the remaining evaluation period. For revefenacin doses $\geq 88 \mu \mathrm{g}$, LS mean placebo-adjusted increases in AM and PM PEF showed clinically relevant improvements of approximately $27 \mathrm{~L} / \mathrm{min}$ and $29 \mathrm{~L} / \mathrm{min}$, respectively. In 
Table 1 Baseline demographics and clinical characteristics (ITT population)

\begin{tabular}{|c|c|c|c|c|c|c|}
\hline & \multirow[b]{2}{*}{$\begin{array}{l}\text { Placebo } \\
(n=70)\end{array}$} & \multicolumn{4}{|l|}{ Revefenacin } & \multirow[b]{2}{*}{$\begin{array}{l}\text { Total } \\
(N=354)\end{array}$} \\
\hline & & $\begin{array}{l}44 \mu \mathrm{g} \\
(n=68)\end{array}$ & $\begin{array}{l}88 \mu \mathrm{g} \\
(n=71)\end{array}$ & $\begin{array}{l}175 \mu \mathrm{g} \\
(n=71)\end{array}$ & $\begin{array}{l}350 \mu \mathrm{g} \\
(n=74)\end{array}$ & \\
\hline \multicolumn{7}{|l|}{ Age (years) } \\
\hline Mean (SD) & $62.2(9.17)$ & $60.9(8.87)$ & $60.4(7.98)$ & $64.5(7.69)$ & $61.4(8.98)$ & $61.9(8.63)$ \\
\hline \multicolumn{7}{|l|}{$\operatorname{Sex}(\%)$} \\
\hline Male & $37(52.9)$ & $32(47.1)$ & $32(45.1)$ & $37(52.1)$ & $40(54.1)$ & $178(50.3)$ \\
\hline Female & $33(47.1)$ & $36(52.9)$ & $39(54.9)$ & $34(47.9)$ & $34(45.9)$ & $176(49.7)$ \\
\hline \multicolumn{7}{|l|}{ Race (\%) } \\
\hline White & $65(92.9)$ & $63(92.6)$ & $64(90.1)$ & $65(91.5)$ & $67(90.5)$ & $324(91.5)$ \\
\hline Black/African American & $4(5.7)$ & $4(5.9)$ & $6(8.5)$ & $5(7.0)$ & $6(8.1)$ & $25(7.1)$ \\
\hline Other & $1(1.4)$ & $1(1.5)$ & $1(1.4)$ & $1(1.4)$ & $1(1.4)$ & $5(1.4)$ \\
\hline \multicolumn{7}{|l|}{ BMI $\left(\mathrm{kg} / \mathrm{m}^{2}\right)$} \\
\hline Mean (SD) & $27.6(5.73)$ & $27.9(6.87)$ & $27.0(5.92)$ & $28.0(5.30)$ & $29.0(5.76)$ & $27.9(5.93)$ \\
\hline \multicolumn{7}{|l|}{ Current smoker (\%) } \\
\hline Yes & $35(50.0)$ & $40(58.8)$ & $44(62.0)$ & $33(46.5)$ & $38(51.4)$ & $190(53.7)$ \\
\hline \multicolumn{7}{|c|}{ Smoking duration (pack-years) } \\
\hline Mean (SD) & $38.2(9.71)$ & $39.3(11.59)$ & $38.9(10.16)$ & $41.2(10.01)$ & $39.6(9.04)$ & $39.5(10.11)$ \\
\hline \multicolumn{7}{|l|}{ Current ICS use (\%) } \\
\hline Yes & $29(41.4)$ & $25(36.8)$ & $24(33.8)$ & $26(36.6)$ & $26(35.1)$ & $130(36.7)$ \\
\hline \multicolumn{7}{|l|}{ Pre-dose $\mathrm{FEV}_{1}(\mathrm{~mL})$} \\
\hline Mean (SD) & $1205.0(473.00)$ & $1279.0(470.10)$ & $1321.0(441.58)$ & $1267.2(415.67)$ & $1338.8(483.95)$ & $1282.6(457.25)$ \\
\hline \multicolumn{7}{|l|}{ Pre-dose $\mathrm{FEV}_{1} / \mathrm{FVC}(\%)$} \\
\hline $\mathrm{n}$ & 70 & 68 & 71 & 71 & 72 & 352 \\
\hline Mean (SD) & $0.50(0.11)$ & $0.51(0.11)$ & $0.52(0.09)$ & $0.51(0.10)$ & $0.52(0.09)$ & $0.51(0.10)$ \\
\hline \multicolumn{7}{|c|}{ Percent predicted post-bronchodilator FEV $_{1}(\%)$} \\
\hline $\mathrm{n}$ & 70 & 68 & 71 & 71 & 72 & 352 \\
\hline Mean (SD) & $41.2(13.00)$ & $43.0(13.35)$ & $45.1(12.43)$ & $44.0(11.76)$ & $44.5(12.35)$ & $43.6(12.58)$ \\
\hline
\end{tabular}

Abbreviations: BMI body mass index, FEV 1 forced expiratory volume in $1 \mathrm{~s}$, FVC forced vital capacity, ICS inhaled corticosteroid, ITT intent to treat, SD standard deviation

contrast, the PEF response for revefenacin $44 \mu \mathrm{g}$ fell below that of the other doses for the majority of the evaluation period.

\section{Pharmacokinetics}

Plasma concentration data were received and analyzed for 34 subjects treated with revefenacin $44,88,175$ or $350 \mu \mathrm{g}$ for 28 days. Median $t_{\max }$ values ranged from 0.483 to $0.517 \mathrm{~h}$ and mean $C_{\max }$ values ranged from 0.0203 to $0.146 \mathrm{ng} / \mathrm{mL}$ (Table 3). After reaching maximum concentrations, revefenacin concentrations declined rapidly in a biphasic manner and were followed by a slow apparent terminal elimination phase characterized by mean $t_{1 / 2}$ values of 51.9 and $57.9 \mathrm{~h}$ at the $175-$ and $350-\mu \mathrm{g}$ dose levels, respectively. Mean $\mathrm{AUC}_{0-24}$ values ranged from 0.0347 to $0.365 \mathrm{ng} \cdot \mathrm{hr} . / \mathrm{mL}$, and mean $\mathrm{AUC}_{0-\mathrm{t}}$ values ranged from 0.0299 to $0.724 \mathrm{ng} \cdot \mathrm{hr} . / \mathrm{mL}$. Relative to the $44 \mu \mathrm{g}$ dose, mean $\mathrm{C}_{\max }$ and AUC values increased with the increases in dose level. Conclusions with respect to dose proportionality were not drawn in this study due to the high variability and limited sample size in each dose group.

\section{Safety}

Of the 355 patients in the safety population, 328 (92.4\%) completed the study per protocol. Twelve of 355 subjects (3.4\%) had an AE that led to permanent treatment discontinuation, which occurred more frequently in the two highest-dose revefenacin treatment groups $(7.0 \%[n=71]$ and $5.4 \%[n=74]$ in the $175 \mu \mathrm{g}$ and $350 \mu \mathrm{g}$ groups, respectively) than in the other treatment groups $(1.4 \%[n=71], 1.5 \%[n=68]$ and $1.4 \%$ $[n=71]$ in the placebo and revefenacin $44 \mu \mathrm{g}$ and $88 \mu \mathrm{g}$ groups, respectively). With the exception of one event of respiratory distress experienced by a placebo patient, all events resolved. 
Table 2 Summary of key spirometric measurements (ITT population)

\begin{tabular}{|c|c|c|c|c|c|}
\hline & \multirow[b]{2}{*}{ Placebo } & \multicolumn{4}{|l|}{ Revefenacin } \\
\hline & & $44 \mu \mathrm{g}$ & $88 \mu \mathrm{g}$ & $175 \mu \mathrm{g}$ & $350 \mu \mathrm{g}$ \\
\hline \multicolumn{6}{|l|}{$\mathrm{D} 28^{\mathrm{a}}$ trough $\mathrm{FEV}_{1}$ change from baseline, $\mathrm{mL}$} \\
\hline$n$ & 55 & 60 & 63 & 59 & 63 \\
\hline LS mean (SE) & $-32.4(25.36)$ & $19.4(24.98)$ & $155.0(24.61)$ & $134.2(25.07)$ & $138.2(24.38)$ \\
\hline LS mean difference from placebo $(95 \% \mathrm{Cl})$ & NA & $51.8(-17.3,121.0)$ & $187.4(118.8,256.1)^{* *}$ & $166.6(97.3,236.0)^{* *}$ & $170.6(101.9,239.3)^{* *}$ \\
\hline \multicolumn{6}{|l|}{ D1 weighted mean $\mathrm{FEV}_{1(0-6 \mathrm{~h}),} \mathrm{mL}$} \\
\hline $\mathrm{n}$ & 69 & 66 & 68 & 70 & 70 \\
\hline LS mean (SE) & $33.3(15.93)$ & $145.1(16.57)$ & $193.8(16.42)$ & $180.0(16.06)$ & $214.9(15.98)$ \\
\hline LS mean difference from placebo $(95 \% \mathrm{Cl})$ & NA & $111.7(67.6,155.9)^{* *}$ & $160.5(116.4,204.5)^{* *}$ & $146.7(103.2,190.2)^{* *}$ & $181.5(138.1,225.0)^{* *}$ \\
\hline \multicolumn{6}{|l|}{ D28 weighted mean $\mathrm{FEV}_{1(0-12 \mathrm{~h}), \mathrm{mL}}$} \\
\hline$n$ & 55 & 63 & 63 & 59 & 64 \\
\hline LS mean (SE) & $-32.8(27.03)$ & $34.3(26.13)$ & $129.8(26.10)$ & $123.4(26.88)$ & $143.1(25.42)$ \\
\hline LS mean difference from placebo $(95 \% \mathrm{Cl})$ & NA & $67.1(-4.9,139.2)$ & $162.6(90.5,234.7)^{* *}$ & $156.2(83.0,229.4)^{* *}$ & $176.0(104.3,247.7)^{* *}$ \\
\hline \multicolumn{6}{|l|}{ D28 weighted mean $\mathrm{FEV}_{1(0-24 \mathrm{~h}), \mathrm{mL}}$} \\
\hline $\mathrm{n}$ & 54 & 59 & 63 & 59 & 62 \\
\hline LS mean (SE) & $-78.1(25.46)$ & $3.4(25.21)$ & $87.0(24.50)$ & $84.1(24.97)$ & $96.3(24.13)$ \\
\hline LS mean difference from placebo $(95 \%$ Cl) & NA & $81.5(12.8,150.2)^{*}$ & $165.1(97.2,233.0)^{* *}$ & $162.1(93.4,230.8)^{* *}$ & $174.3(106.5,242.2)^{* *}$ \\
\hline
\end{tabular}

${ }^{*} p=0.02,{ }^{* *} p<0.001$ versus placebo

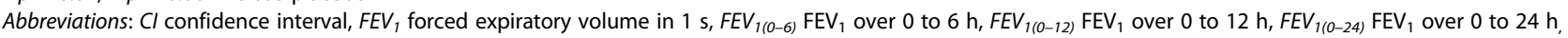

ITT intent-to-treat, LS least squares, NA not applicable, SE standard error

${ }^{\mathrm{a} D} 28$ trough $\mathrm{FEV}_{1}$ measured on D29

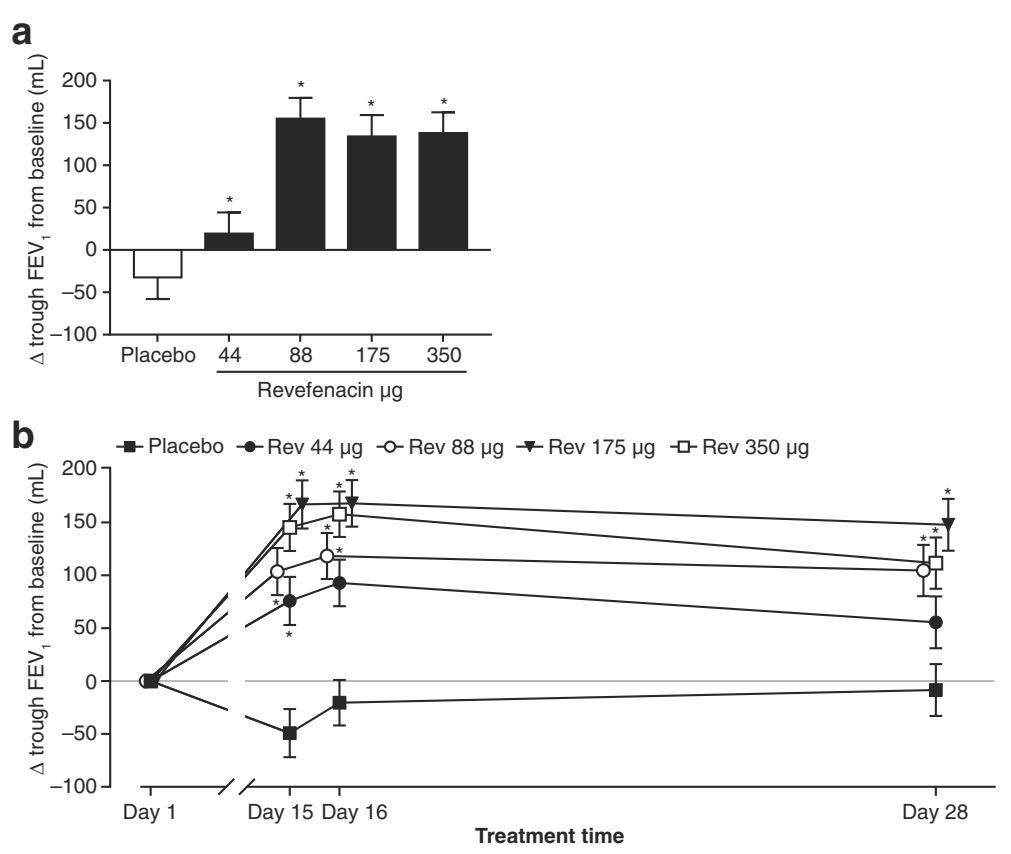

Fig. 2 Change from baseline in trough $\mathrm{FEV}_{1}$. a D28 $8^{\mathrm{a}}$ trough $\mathrm{FEV}_{1}$ and $\mathbf{b}$ trough $\mathrm{FEV}_{1}$ on D1, D15, D16 and D28. Data presented as LS mean \pm SE. ${ }^{*} p<0.001$

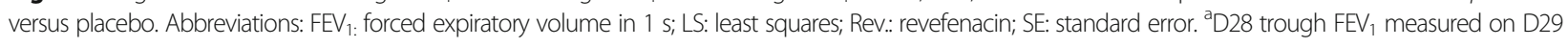




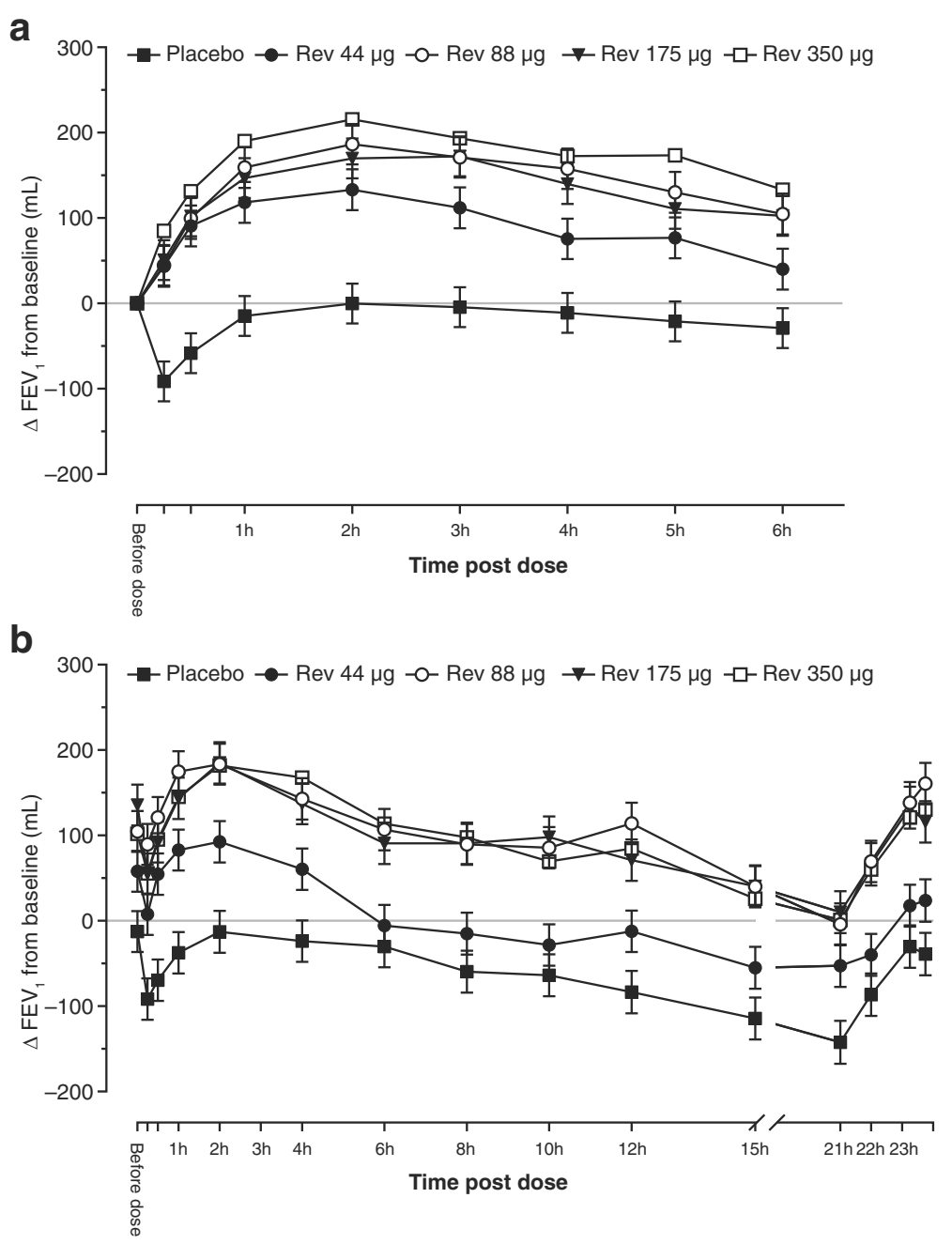

Fig. 3 Change from baseline in serial FEV 1 on Day 1 (a) and Day 28 (b). Data presented as LS mean \pm SE. Abbreviations: FEV ${ }_{1}$ : forced expiratory volume in $1 \mathrm{~s}$; h: hours; LS: least squares, Rev.: revefenacin; SE: standard error

Revefenacin was generally well tolerated, and the frequency of AEs was broadly comparable across all treatment groups, including placebo. Headache, shortness of breath and cough were the three most common AEs in the study (Table 4). A small number of treated subjects (five of 355) experienced worsening of COPD (four exacerbations and one worsening of symptoms) during the course of the study; these subjects were withdrawn from the study and treated appropriately.

Four SAEs were reported during the study; one in the $44 \mu \mathrm{g}$ group (supraventricular tachycardia), two in the $175 \mu \mathrm{g}$ group (unstable angina and hypertension) and one in the $350 \mu \mathrm{g}$ group (intestinal obstruction). One of the four SAEs (supraventricular tachycardia) was considered by the blinded investigator to be possibly related to revefenacin, but an independent assessment by a blinded cardiologist confirmed that the condition was present during screening, the change following dosing was minimal and the likelihood of a relationship between this SAE and the study medication was low. All four SAEs resolved, but the subjects with cases of supraventricular tachycardia and unstable angina were withdrawn from the study.

AEs traditionally associated with inhaled anti-muscarinic agents were infrequent. Two incidents of dry mouth (one each in the $88 \mu \mathrm{g}$ and $350 \mu \mathrm{g}$ groups; both mild in severity) were observed, but no incidents of constipation, urinary retention, dysuria, blurred vision or glaucoma were reported.

Holter monitoring findings were unremarkable for changes of mean, maximum or minimum heart rates during the recording period, with no findings that were uniquely associated with revefenacin dosing or that were clearly more prominent with increasing revefenacin dose level.

\section{Discussion}

This study characterized the efficacy and safety of revefenacin $(44,88,175$ or $350 \mu \mathrm{g})$ after 28 days of once- 

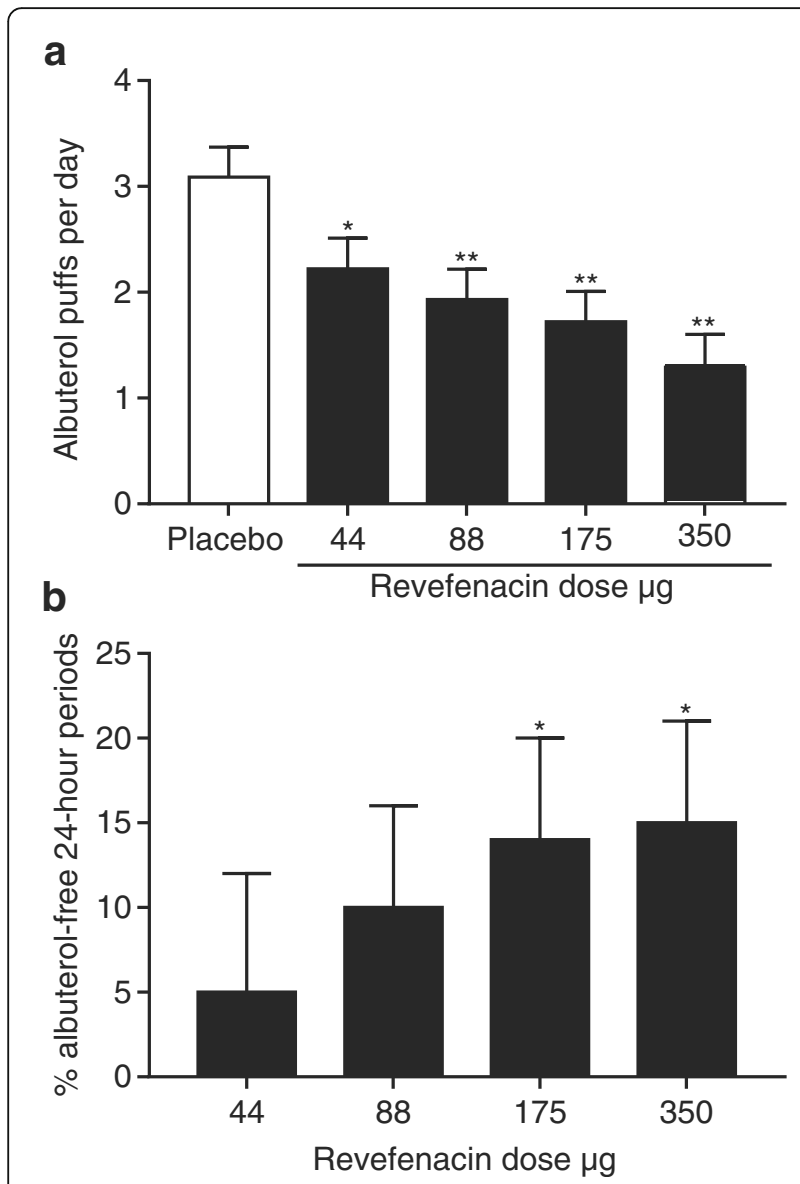

Fig. 4 Effect of revefenacin on rescue medication use. a albuterol puffs per day; data presented as LS mean \pm SE. $\mathbf{b}$ percent of albuterol-free 24-h periods over the entire treatment period; data presented as LS mean difference from placebo \pm SE. ${ }^{*} p<0.05 ;{ }^{* *} p<0.005$. Abbreviations: LS: least squares; SE: standard error

daily administration to patients with moderate to severe COPD. Revefenacin at doses $\geq 88 \mu \mathrm{g}$ led to significant improvements in the primary endpoint (change from baseline in D28 trough $\mathrm{FEV}_{1}$ ). The trough $\mathrm{FEV}_{1}$ improvements with the 88 and $175 \mu \mathrm{g}$ dose (155 and $134 \mathrm{~mL}$, respectively) are comparable to reported values for tiotropium bromide (126 mL) [21] delivered with the Respimat ${ }^{\oplus}$ soft mist inhaler.

As a novel once-daily LAMA, revefenacin may be differentiated from the currently available once-daily tiotropium and umeclidinium handheld products in important ways. Revefenacin's novel biphenyl carbamate tertiatry amine structure is distinct from the quaternary ammonium antagonists, [22] thus representing the first inhaled LAMA of its class to enter clinical development for COPD. The revefenacin discovery program was designed to select a 24-h-duration LAMA endowed with chemical stability (enabling long-term storage as a preservative-free aqueous solution product), high lung-to-salivary gland functional selectivity (vida infra) and a metabolically labile primary amide "soft-drug" site to allow rapid systemic clearance of the parent drug, thus potentially minimizing systemically mediated adverse events [16].

The high metabolic lability of revefenacin contrasts with the relative metabolic stability of tiotropium and its primarily renal systemic clearance profile. Instead, revefenacin shares umeclidinium's profile of rapid metabolic turnover after distributing from the lung [23]. Systemic clearance of revefenacin is primarily via enzymatic hydrolysis versus cytochrome P450 (CYP2D6)-mediated oxidative turnover for umeclidinium [24]. Finally, the revefenacin drug product in the current study is administered via a standard jet nebulizer. This unique presentation of a once-daily bronchodilator may be of future therapeutic benefit to those patients who prefer or require nebulization therapy [9].

The sustained 24-h bronchodilator response observed previously in a 7-day study of revefenacin in patients with moderate to severe COPD [17] was supported here by the numerical similarity of trough $\mathrm{FEV}_{1}$ values to the D1 and D28 weighted mean FEV 1 values. A sustained response was further supported by the observation of increased morning and evening PEFs throughout the treatment period, which is consistent with reports of once-daily tiotropium following 3 or 4 weeks of dosing in patients with moderate to severe COPD [21, 25]. In addition, patients treated with revefenacin used less rescue albuterol throughout the 4-week treatment period, in keeping with reduced rescue medication use reported for tiotropium [21] following 4 and 12 weeks of dosing.

Revefenacin was generally well tolerated and did not produce systemic effects typically associated with anticholinergic therapies, such as dry mouth, urinary retention, tachycardia or acute closed-angle glaucoma [26]. The incidence of dry mouth $(1.4 \%$ for both 175 and $350 \mu \mathrm{g}$ ) was lower than the $4 \%$ incidence reported in a comparable 3-week study of $5 \mu \mathrm{g}$ tiotropium administered with the Respimat soft mist inhaler in patients with COPD [25]. In addition, the revefenacin safety profile observed here was consistent with pre-clinical studies that revealed a superior lung selectivity index (ratio of anti-sialagogue to bronchoprotective potency) with inhaled revefenacin compared with either glycopyrronium or tiotropium [27]. Moreover, the favorable AE profile of revefenacin in this study is supported by a 7 day multiple-dose study of revefenacin $(22$ to $350 \mu \mathrm{g})$ in patients with moderate to severe COPD [17] in which the frequency of AEs was comparable across all treatment groups, including placebo.

The efficacy and safety data from this study indicate that revefenacin 88 and $175 \mu \mathrm{g}$ represent apppropriate doses for use in longer-term safety and efficacy trials. The trough $\mathrm{FEV}_{1}$ data indicated that $44 \mu \mathrm{g}$ was a subtherapeutic revefenacin dose compared with the three 

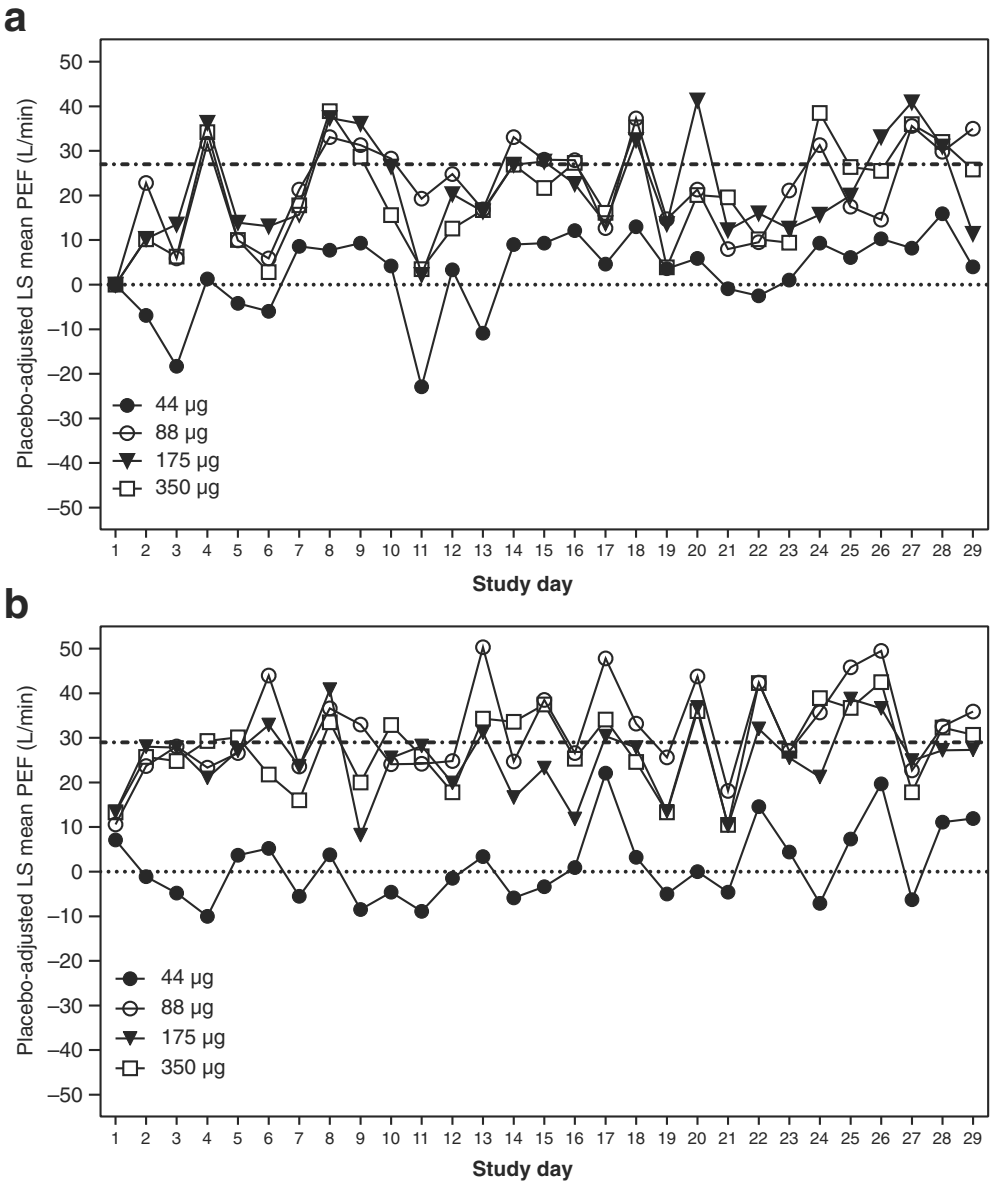

Fig. 5 Effect of revefenacin on daily peak expiratory flow rate. a morning PEF (representative of the trough PEF of the prior day's dosing). $\mathbf{b}$ evening $P E F$, assessed $\approx 12 \mathrm{~h}$ after daily study medication dosing. Data presented as placebo-adjusted LS mean; dotted line (........) = zero L/min; dashed line ( $-\ldots .$. represents LS mean placebo-adjusted increases in AM and PM PEF for revefenacin doses $\geq 88 \mu \mathrm{g}$, which were similar across the treatment period and centered at approximately $27 \mathrm{~L} / \mathrm{min}$ and $29 \mathrm{~L} / \mathrm{min}$, respectively. Abbreviations: LS: least squares; PEFR: peak expiratory flow rate

Table 3 Summary of mean plasma pharmacokinetic parameters ${ }^{a}$

\begin{tabular}{|c|c|c|c|c|c|}
\hline Dose $(\mu \mathrm{g})$ & $C_{\max }(\mathrm{ng} / \mathrm{mL})$ & $t_{\max }(h r)$ & $A \cup C_{0-24}(\mathrm{ng} \bullet \mathrm{hr} . / \mathrm{mL})$ & $\mathrm{AUC}_{0-\mathrm{t}}(\mathrm{ng} \bullet \mathrm{hr} . / \mathrm{mL})$ & $\mathrm{t}_{1 / 2}(\mathrm{hr})$ \\
\hline 44 & $0.0203 \pm 0.0124$ & $0.483(0.350,0.500)$ & $0.0347 \pm 0.0106$ & $0.0299 \pm 0.0098$ & $N C^{b}$ \\
\hline$n$ & 7 & 7 & 4 & 4 & 1 \\
\hline 88 & $0.0282 \pm 0.0157$ & $0.500\left(0.417,12.3^{\mathrm{c}}\right)$ & $0.155 \pm 0.0749$ & $0.129 \pm 0.0589$ & NC \\
\hline$n$ & 9 & 9 & 6 & 6 & 0 \\
\hline 175 & $0.121 \pm 0.157$ & $0.517(0.467,0.767)$ & $0.351 \pm 0.364$ & $0.720 \pm 0.864$ & $51.9 \pm 31.5$ \\
\hline$n$ & 9 & 9 & 9 & 9 & 5 \\
\hline 350 & $0.146 \pm 0.148$ & $0.500(0.433,0.583)$ & $0.365 \pm 0.306$ & $0.724 \pm 0.833$ & $57.9 \pm 31.5$ \\
\hline$n$ & 8 & 8 & 8 & 8 & 7 \\
\hline
\end{tabular}

${ }^{a}$ Data are mean \pm SD except for $t_{\max }$ data which are median (minimum, maximum)

${ }^{{ }^{b}} T_{1 / 2}$ values were not calculated for the majority of subjects at revefenacin 44 and $88 \mu \mathrm{g}$ due to limited data at these dose levels

'The concentration observed at this $t_{\max }$ value was considered to be high compared to the rest of the subject's profile and was reanalyzed. Reanalysis confirmed the original result, and the value was included in PK analysis

Abbreviations: $A U C_{0-24}$ area under the curve for plasma concentration-time from time 0 to $24 \mathrm{~h}, A \cup C_{0-t}$ area under the curve for plasma concentration-time from time 0 to the last detectable time point, $C_{\text {max }}$ maximum plasma concentration, $h r$. hours, $N C$ not calculated, $P K$ pharmacokinetics, $S D$ standard deviation, $t_{1 / 2}$ terminal elimination half-life, $t_{\max }$ time to maximum plasma concentration 
Table 4 Treatment-emergent AEs reported in $\geq 1 \%$ of any treatment group (safety population)

\begin{tabular}{|c|c|c|c|c|c|c|}
\hline \multirow[b]{2}{*}{ Patients with an $A E, n(\%)$} & \multirow[b]{2}{*}{$\begin{array}{l}\text { Placebo } \\
(n=71)\end{array}$} & \multicolumn{4}{|c|}{ Revefenacin } & \multirow[b]{2}{*}{$\begin{array}{l}\text { Total } \\
(N=355)\end{array}$} \\
\hline & & $\begin{array}{l}44 \mu \mathrm{g} \\
(n=68)\end{array}$ & $\begin{array}{l}88 \mu \mathrm{g} \\
(n=71)\end{array}$ & $\begin{array}{l}175 \mu \mathrm{g} \\
(n=71)\end{array}$ & $\begin{array}{l}350 \mu \mathrm{g} \\
(n=74)\end{array}$ & \\
\hline Any AEs & $22(31.0)$ & $16(23.5)$ & $26(36.6)$ & $22(31.0)$ & $23(31.1)$ & $109(30.7)$ \\
\hline \multicolumn{7}{|l|}{ Preferred term } \\
\hline Headache & $2(2.8)$ & $1(1.5)$ & $2(2.8)$ & $1(1.4)$ & $5(6.8)$ & $11(3.1)$ \\
\hline Dyspnea & $2(2.8)$ & 0 & $3(4.2)$ & $3(4.2)$ & $2(2.7)$ & $10(2.8)$ \\
\hline Cough & $1(1.4)$ & 0 & 0 & $3(4.2)$ & $3(4.1)$ & $7(2.0)$ \\
\hline $\mathrm{COPD}^{\mathrm{a}}$ & $2(2.8)$ & 0 & 0 & $1(1.4)$ & $2(2.7)$ & $5(1.4)$ \\
\hline Back pain & 0 & 0 & $1(1.4)$ & $2(2.8)$ & $1(1.4)$ & $4(1.1)$ \\
\hline Oropharyngeal pain & $1(1.4)$ & $1(1.5)$ & 0 & 0 & $2(2.7)$ & $4(1.1)$ \\
\hline
\end{tabular}

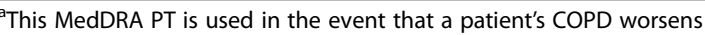

Abbreviations: AE adverse event, COPD chronic obstructive pulmonary disease, MedDRA Medical Dictionary for Regulatory Activities, PT preferred term

higher doses. Additionally, the $350 \mu \mathrm{g}$ dose did not demonstrate additional efficacy over that observed with $175 \mu \mathrm{g}$ revefenacin. Limitations of this study include the small number of patients and the relatively short 4-week treatment period, which limit conclusions regarding the potential clinical benefits of revefenacin. However, the data from this study have informed dose selection for longer-term phase 3 clinical trials investigating the safety [15] and efficacy [14] of revefenacin in patients with moderate to very severe COPD. The results of those studies may reveal the potential clinical benefits of revefenacin in patients with COPD.

More broadly, certain COPD patient populations may especially benefit from the use of nebulizer therapy, such as those with chronic muscle weakness, the elderly and those with cognitive or visual impairment or diminished manual dexterity [6]. In general, these patients also prefer nebulized therapy when hospitalized for exacerbations of COPD [23]. Currently these patients are managed with nebulized twice-daily long-acting betaagonists (arformoterol tartrate and formoterol fumarate) or short-acting nebulized agents requiring four-times a day dosing. Revefenacin, if approved, could offer patients who require or prefer nebulized therapy the opportunity to be treated with a once-daily LAMA, as has been standard practice for many years in COPD patients who can use handheld devices containing the once-daily LAMAs (including tiotropium and umeclidinium) [22]. Additionally, revefenacin would represent the first oncedaily LAMA approved for nebulized therapy, with similar efficacy to tiotropium but with less potential for antimuscarinic side effects (eg, dry mouth) $[9,28]$.

\section{Conclusion}

Once-daily revefenacin increased trough $\mathrm{FEV}_{1}$ in patients with moderate to severe COPD, with 88 and $175 \mu \mathrm{g}$ revefenacin identified as the optimal doses for use in longerterm safety and efficacy studies. Revefenacin has the potential to be the first once-daily long-acting bronchodilator for use in patients who require or prefer nebulized anti-muscarinic therapy.

\section{Endnotes}

${ }^{1} \mathrm{~A}$ preliminary abstract of this study was previously published: Nicholls AJ, Barnes C, Bourdet DL, Moran EJ, Haumann B. Dose-Ranging Study Of Once-Daily TD-4208, An Inhaled Long-Acting Muscarinic Antagonist (LAMA) In Patients With Chronic Obstructive Pulmonary Disease (COPD). Am J Respir Crit Care Med. 2015;191:A5750 [Abstract].

\section{Abbreviations}

AE: Adverse event; AUC: Area under the curve; AUC $0-24$ : AUC for plasma concentration-time from time 0 to $24 \mathrm{~h}$; $\mathrm{AUC}_{0-\mathrm{t}}$ : AUC for plasma concentration-time from time 0 to to the last detectable time point; $\mathrm{Cl}$ : Confidence interval; $\mathrm{C}_{\max }$ : Maximum plasma concentration; COPD: Chronic obstructive pulmonary disease; ECG: Electrocardiogram; $\mathrm{FEV}_{1}$ : Forced expiratory volume in $1 \mathrm{~s}$; $\mathrm{FEV}_{1(0-12)}$ : Forced expiratory volume in $1 \mathrm{~s}$ over 0 to $12 \mathrm{~h}$; FEV $\mathrm{V}_{1(0-24)}$ : Forced expiratory volume in $1 \mathrm{~s}$ over 0 to $24 \mathrm{~h}$;

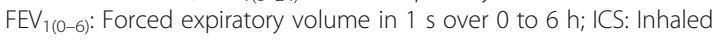
corticosteroids; ITT: Intent to treat; LABA: Long-acting beta agonist; LAMA: Long-acting muscarinic antagonist; LS: Least squares; MedDRA: Medical Dictionary for Regulatory Activities; NC: Not calculated; PEF: Peak expiratory flow; PK: Pharmacokinetic; PT: Preferred term; QTCF: Fridericia formula for QT interval correction; REV: Revefenacin; SAE: Serious adverse event; SD: Standard deviation; SE: Standard error; $t_{1 / 2}$ : Terminal elimination half-life; $t_{\text {max }}$ : Time to maximum plasma concentration

\section{Acknowledgements}

The authors wish to acknowledge Roger Hill, PhD, for medical writing and Paula Stuckart for editorial assistance in the preparation of the manuscript (Ashfield Healthcare Communications, Middletown, CT, USA).

\section{Funding}

This study was funded by Theravance Biopharma, Inc. (George Town, Cayman Islands). Mylan Inc. (Canonsburg, Pennsylvania, USA) and Theravance Biopharma (San Francisco, CA, USA) funded medical writing support.

Availability of data and materials

All authors had access to the data included in the manuscript. The datasets generated during the current study are not publicly available but can be requested from the corresponding author. 


\section{Authors' contributions}

All authors contributed to the conception and design, or acquisition of data or analysis and interpretation of data; drafting the manuscript or revising it critically for important intellectual content; gave final approval of the version to be published and agreed to be accountable for all aspects of the work, ensuring that questions related to the accuracy or integrity of any part of the work are appropriately investigated and resolved.

\section{Ethics approval and consent to participate}

The protocol and all amendments were approved by local review boards, ethics committees and health authorities at each of the 41 study centers. All patients provided written informed consent.

\section{Consent for publication}

Not applicable.

\section{Competing interests}

$\mathrm{KP}$ has no disclosures. $\mathrm{CB}, \mathrm{EM}$ and $\mathrm{BH}$ are employees of the Theravance Biopharma group of companies. EK is a consultant for Amphastar, Astra Zeneca, Forest, Mylan, Novartis, Sunovion, Teva and Theravance Biopharma.

\section{Publisher's Note}

Springer Nature remains neutral with regard to jurisdictional claims in published maps and institutional affiliations.

\section{Author details}

${ }^{1}$ Upstate Pharmaceutical Research, Greenville, SC, USA. ${ }^{2}$ Theravance Biopharma US, Inc., South San Francisco, CA, USA. ${ }^{3}$ Theravance Biopharma UK Limited, London, UK. ${ }^{4}$ Clinical Research Institute of Southern Oregon, PC, Medford, OR, USA

Received: 15 March 2017 Accepted: 22 August 2017

\section{Published online: 02 November 2017}

\section{References}

1. Vogelmeier CF, Criner GJ, Martinez FJ, et al. Global strategy for the diagnosis, management, and prevention of chronic obstructive lung disease 2017 report. GOLD executive summary. Am J Respir Crit Care Med. 2017; 195(5):557-82

2. Barjaktarevic IZ, Arredondo AF, Cooper CB. Positioning new pharmacotherapies for COPD. Int J Chron Obstruct Pulmon Dis. 2015;10: 1427-42.

3. Montuschi P, Macagno F, Valente S, Fuso L. Inhaled muscarinic acetylcholine receptor antagonists for treatment of COPD. Curr Med Chem. 2013;20:1464-76.

4. Fuso L, Mores N, Valente S, Malerba M, Montuschi P. Long-acting betaagonists and their association with inhaled corticosteroids in COPD. Curr Med Chem. 2013;20:1477-95.

5. Vincken W. Bronchodilator treatment of stable COPD: long-acting anticholinergics. Eur Respir Rev. 2005;14:23-31.

6. Bonini M, Usmani OS. The importance of inhaler devices in the treatment of COPD. COPD Res Pract. 2015;1:1-9.

7. Lavorini F, Corrigan CJ, Barnes PJ. Retail sales of inhalation devices in European countries: so much for a global policy. Respir Med. 2011;105: 1099-103.

8. Dhand R, Dolovich M, Chipps B, Myers TR, Restrepo R, Farrar JR. The role of nebulized therapy in the management of COPD: evidence and recommendations. COPD. 2012;9:58-72.

9. Tashkin DP. A review of nebulized drug delivery in COPD. Int J Chron Obstruct Pulmon Dis. 2016:11:2585-96.

10. Quinet $P$, Young CA, Heritier $F$. The use of dry powder inhaler devices by elderly patients suffering from chronic obstructive pulmonary disease. Ann Phys Rehabil Med. 2010;53:69-76.

11. Mahler DA, Waterman LA, Ward J, Gifford AH. Comparison of dry powder versus nebulized beta-agonist in patients with COPD who have suboptimal peak inspiratory flow rate. J Aerosol Med Pulm Drug Deliv. 2014;27:103-9.

12. Sulaiman I, Cushen B, Greene $G$, et al. Objective assessment of adherence to inhalers by COPD patients. Am J Respir Crit Care Med. 2017;195:1333-43.

13. Dolovich MB, Ahrens RC, Hess DR, et al. Device selection and outcomes of aerosol therapy: Evidence-based guidelines: American College of Chest Physicians/American College of Asthma, Allergy, and Immunology. Chest. 2005;127:335-71.
14. Pudi K, Pendyala S, Barnes C, Moran E, Haumann B, Kerwin E. Trials in progress: two 12-week, randomized, double-blind, placebo-controlled, parallel-group phase 3 trials of a nebulized long-acting muscarinic antagonist (revefenacin) in study participants with moderate to very severe COPD. Chest. 2016;150:825A. [Abstract]

15. DeLaCruz L, Pendyala S, Barnes C, Moran E, Haumann B, Feldman G. Trial in progress: a 52-week, randomized, double-blind, placebo-controlled, parallelgroup phase 3 trial to evaluate the safety and tolerability of a nebulized long-acting muscarinic antagonist (Revefenacin) in study participants with COPD. Chest. 2016;150:866A. [Abstract]

16. Ji Y, Husfeld C, Pulido-Rios MT, et al. Duration by design: discovery of Revefenacin, the first-in-class Nebulized once-daily bronchodilator for the treatment of patients with COPD. Chest. 2016;150:970A. [Abstract]

17. Nicholls A, Barnes C, Yates W, Moran E, Singh D. A randomized, crossover, 7day study of once-daily TD-4208, a long-acting muscarinic antagonist, in subjects with COPD. Am J Respir Crit Care Med. 2014;189:A6003. [Abstract]

18. $\mathrm{I} \mathrm{CH}$. Integrated addendum to $\mathrm{ICH}$ harmonised guideline: guideline for good clinical practice E6 (R2). https://goo.gl/CFOmR3. Accessed 20 Jul 2017.

19. World Medical Association Declaration of Helsinki: ethical principles for medical research involving human subjects. JAMA. 2013;310:2191-2194.

20. Miller MR, Hankinson J, Brusasco V, et al. Standardisation of spirometry. Eur Respir J. 2005:26:319-38.

21. van Noord JA, Cornelissen PJ, Aumann JL, Platz J, Mueller A, Fogarty C. The efficacy of tiotropium administered via Respimat Soft Mist Inhaler or HandiHaler in COPD patients. Respir Med. 2009;103:22-9.

22. Montuschi $\mathrm{P}$, Ciabattoni $\mathrm{G}$. Bronchodilating drugs for chronic obstructive pulmonary disease: current status and future trends. J Med Chem. 2015;58:4131-64.

23. Babu KS, Morjaria JB. Umedidinium in chronic obstructive pulmonary disease: latest evidence and place in therapy. Ther Adv Chronic Dis. 2017;8:81-91.

24. GlaxoSmithKline. Incruse Ellipta ${ }^{\oplus}$ (umeclidinium inhalation powder) [prescribing information]. Research Triangle Park. http://bit.ly/2szZfSf. Accessed 21 June 2017.

25. Caillaud D, Le Merre C, Martinat Y, Aguilaniu B, Pavia D. A dose-ranging study of tiotropium delivered via Respimat Soft Mist Inhaler or HandiHaler in COPD patients. Int J Chron Obstruct Pulmon Dis. 2007;2:559-65.

26. Cazzola M, Page CP, Calzetta L, Matera MG. Pharmacology and therapeutics of bronchodilators. Pharmacol Rev. 2012;64:450-504.

27. Pulido-Rios MT, McNamara A, Obedencio GP, et al. In vivo pharmacological characterization of TD-4208, a novel lung-selective inhaled muscarinic antagonist with sustained bronchoprotective effect in experimental animal models. J Pharmacol Exp Ther. 2013:346:241-50.

28. Gross N. The COPD pipeline XXVIII. J COPD Found. 2015;2:259-63.

\section{Submit your next manuscript to BioMed Central and we will help you at every step:}

- We accept pre-submission inquiries

- Our selector tool helps you to find the most relevant journal

- We provide round the clock customer support

- Convenient online submission

- Thorough peer review

- Inclusion in PubMed and all major indexing services

- Maximum visibility for your research

Submit your manuscript at www.biomedcentral.com/submit
) BioMed Central 